\title{
PAPI システムについで
}

\author{
正会員 野間 聖 明*
}

\section{PAPI (Precision Approach Path Ind) 開 発の経緯}

\section{1 大型機の着陸の際の進入角情報の必要性}

大型ジェット機で, 安全にスムーズに着陸するためには 三つの重要なポイントがある。

（1） $3^{\circ}$ の降下角で滑走路に近づき，円滑な操作で高度と 速度を処理する.

（2）滑走路末端を通過するときの高度を，決められた值 に正しく保つ.

（3）着陸の接地点のばらつき範困を，できるだけ小さく する。

これらの点をらまく操作して安全に着陸するためには, 3゚で降下するフライトパスを決めるための基準になるもの が必要となる。その一つ虫, 電波苍利用した ILS（Instrument Landing System) といわれるもので, 滑走路 のそばから指向性のコース電波と降下角電波を発射し, 航 空機はそれを受信して, 雲や霧で視界が恶くても正確に安 全に着陸できる装置である。もら一つは VASIS（Visual Approach Slope Indicator System) で，視覚による進 入角指示灯群である.

これは滑走路の接地点付近の雨側に $150 \sim 210 \mathrm{~m}$ 間隔で, 2 対または 3 対の灯火を並べ, 前方の灯火は赤, 手前の灯 火は白に見えるように降下すると，30の進入角で降下でき るように設置された灯火群である.

\subsection{VASIS の不備の点}

上記のVASIS は，約25年前から各国の空港で広く使用 されているものであるが，航空機の運航方式の発達によっ て，次のような不備な点が指摘されるようになった。

(1) 高度 $60 \mathrm{~m}$ 以下で使用するには，ガイダンス情報の 精度が不十分である。

（2）赤，ピンク，白の色灯を使用しているため，これら の色対比がスモッグなどの気象現象によって悪くなり，そ れが精度不十分につらなることがある。

(3) パターンを構成する灯器の数が多いことが, 設置面 積の制限とか，コスト面からの難点がでてきた.

$\dagger$ Explanation of PAPI System

* 日本航空機操縦士協会

Takaaki Noma

\section{3 精密なガイダンス情報の必要性}

航空機の運航がシステマティックに行なわれるようにな ると，着陸進入中のパイロットが，着陸コースからそれた のをすばやく発見して修正することができ，滑走路末端を 通過するまで利用でき(高度 $15 \mathrm{~m}$ 束で利用できる意味)， かつ接地点のばらつき範囲が小さくなり，天候気象の影響 が少なく，設置面積も取らず，ILS との整合も十分にでき る精密進入着陸援助施設の必要性が高まってきた.

そのころ英国王立航空機研究所 (RAE) に上って, PAPI（精密進入路指示灯）が開発されて，1995年から世 界的に VASISに代わって運用されることになり，その10 年前の今年から空港に設置し運用してよいことが，国際民 間航空条約によって決められている.

日本でも航空局照明課の委託を受计て，照明学会でも研 究が続けられていて，昭和58年 9 月には官民合同で羽田空 港で夜間実験が行なわれた，引き続き仙台空港に仮設して 飛行実験が行なわれて非常によい結果が得られた。

昭和59年11月から 3 か月間, 沖縄の下地帛訓練空港に設 置して央際のフライトによって試験運用が行なわれて，正 式運用への第一歩が踏み出されている.

\section{PAPI の原理}

PAPI ユニットは, 図 1 のように VASIS ニニットの 理論的発展型で, 白色灯々赤色灯拈よびその中間色の 3 色 光によって進入角を指示する，視覚信号の原理を応用した 装置である。

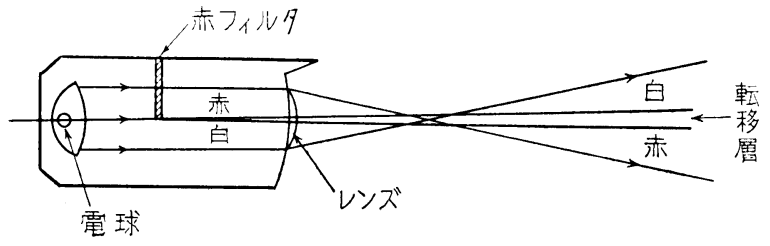

図 1 ユニットの光学的原理

各ユニットは 3 個のランプから成り,フィルタおよびレ ンズにより，上側に白色光，下側に赤色光を照射し，その 中間の転移層 (中間色) の鉛直幅 (弧角) は，3 分以下の 非常にシャープな転移層を形成しており（VASIS の転移 層は15分), 従来の VASIS よりもはるかに精密な情報を, 
パイロットに与えることのできる点光源の組み合わせによ る進入角のガイダンスシステムである.

\subsection{PAPI ユニットの数と配置要領}

PAPI は図 2 の配置図のように, A, B, C, D 4 個 のニニットから成る単一ウイングバーで, 滑走路の接地点 付近の左側のエッヂから $15 \mathrm{~m}$ 離してニニット D, 続いて $\mathrm{C}, \mathrm{B}, \mathrm{A}$ 各ユニットを $9 \mathrm{~m}$ 間隔で配置する。この理由は PAPI は 4 個のニニットがそれぞれ分離して見完て, 赤 2 個と白 2 個でオングライド・スロープである，といら指示 が行なわれるため 4 個は分離していなければならない.こ れに反して VASISは，3個のユニットがくっついて棒に 見えても構わないので $6 \mathrm{~m}$ 間隔になっている.

(配遭圆)

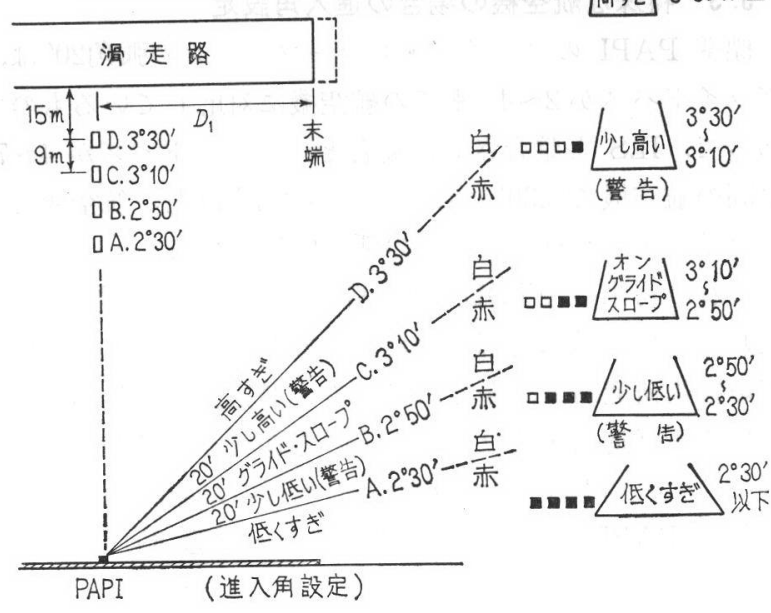

図 2 PAPI の配置, 進入角設定, 見方方

$9 \mathrm{~m}$ むば, 視力 0.5 の目で $15 \mathrm{~km}$ 離れて見て分離して 見えることになる.すなわち視角 2 分に対応した間隔であ る。

パイロットの中心視力は1.0〜 1.2あるけれども, 着陸進 入中の目のつけどころは，常に眼高の 20 倍前方の滑走路中 心線上のエイミングポイント（狙いの点）を注視してい て，そこを中心にして視線のスキャンパスができ上がって いるので，他の対象物に視線が移ってもすぐエイミングポ イントに帰るものであるそそのため PAPI は大部分視力の 劣った周辺視で見ていることが多いので, 視力 0.5 に対応 する $9 \mathrm{~m}$ 間隔が必要だと思われる.

次に滑走路末端から PAPI までの距離 $D_{1}$ (図 2 の配置 図参照）は，PAPI の指示に従って降下寸る航空機が，滑 走路末端を通過する際に, 車輪の高さが $9 \mathrm{~m}$ 以上必要で あるという国際民間航空条約の規定によるもので，機体の 寸法, 滑走路の傾斜, 障害物の有無も含めて計算される が，普通 $450 \mathrm{~m}$ 前後になる。

図 3 は, PAPI を赤, 赤, 白, 白に見て正しくグライ ドスロープ上を降下している，下地島訓練空港のフライト チェックの様子である.

PAPI はこのように滑走路の左側に設置されるのは，国

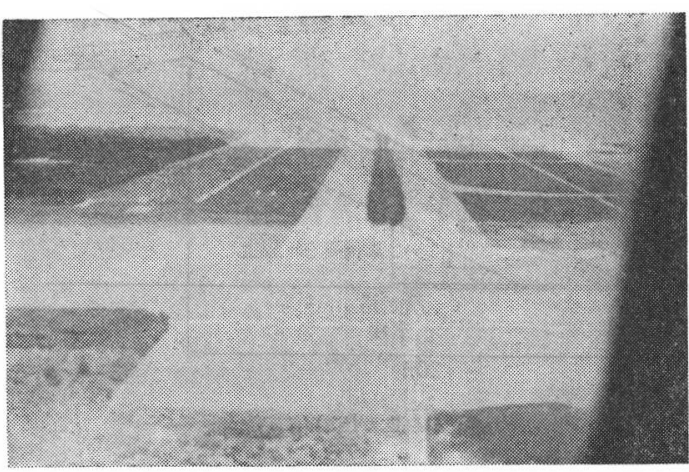

図 3 PAPI のフライトチェック(下地島 $3,000 \mathrm{~m}$ 滑走路〉

際民間航空条約によって決められているわけであるが，そ れは航空機の機長席が左側にあって, 着陸操作を行なら機 長の視線のスキャンパスの中心は, エイミングポイントの わずかに左側の滑走路面であるため, 左側にあるほうが視 線が行さやすいためである.

$\mathrm{ICAO}$ (国際民間航空機関)の視覚援助施設パネル(VAP) 第 9 回報告書によれば、ロンドン空港で行なわれた長期間 の試験運用でも, 両側配置よりも左側配置で良いとのコメ ントが圧倒的に多かったことは，上記のスキャンパスによ ることを物語っていると思われる。

しかし進入灯の設備のないローカル空港では, 滑走路の 両側に配置してもよいことになっている.

\section{PAPI の特長}

PAPI は，悪天候のもとで運航ができるよらに開発され た新器材であるから，今までの VASISなどとは違った特 長がある。

\section{1 標準 PAPI の進入角設定}

PAPI は，A，B，C，D 4 個の灯器から成る 1 本のウ イングバーによって進入角指示を行なうものであって， VASISのように 150〜210 mの間隔で配置された，奥のバ 一と手前のバーからの信号によって, 進入角を定める方式 に比べると, 滑走路に近ついてからの進入角の精度がぐん と精密になって，VASIS よりもさらに悪い天候のときの 運用にも適している.

PAPI の進入角設定の基準は，現用ジェット機の性能と 運用方式がもとになっている.

着陸に際して滑走路に対しての進入角は, プロペラ機で は $2^{\circ} 30^{\prime}$ であったが，現在飛んでいる通常の型をしている ジェット機である, ボーイング727型, ボーイング767型, ダグラス DC-10や，ボーイング747（ジャンボ）などは, 性能の面と運用の面から $3^{\circ}$ の進入角が最適となっている が， $3^{\circ}$ といら角度は操作の面からも図 3 のよ 5 に高さ 1 (h) に対して, 接地点までの 距離である底辺 $20(\mathrm{~h})$ と いら関係が成り立ち, $3^{\circ}$ の斜面を降下するには, 速度の半 分の10倍の降下率 (140)ットならば 700 フィート/分) で 進入すれば，正しく降下することができる特長がある.

これは全く幾何学的なものであるが，パイロットとして 


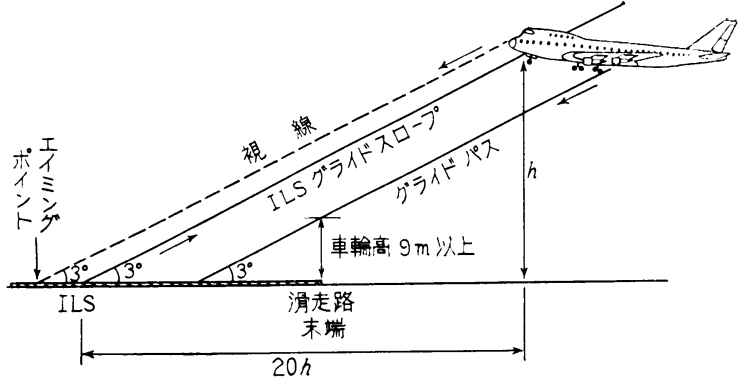

図 4 進入角の相互関係

はきわめて楽に, 正確に $3^{\circ}$ の゙ライド・スロープ上を降下 できるのである。

航空機が PAPI を赤, 赤, 白, 白に見て降下すれば, 進入角が $3^{\circ}$ になり, 滑走路末端通過の際に車輪高が $9 \mathrm{~m}$ 以上になるに進入角を設定するには，図 2 のように滑走路 に最も近いD灯器の白灯と赤灯の境界を $3^{\circ} 30^{\prime}$ に設定し て, これをグライド・スロープの上限とし, 次にC灯器を $3^{\circ} 10^{\prime}$, B灯器を $2^{\circ} 50^{\prime}$ に設定して, グライド・スロープゾ ーンとし, 最も外側の $\mathrm{A}$ 灯器の白灯と赤灯の境界を $2^{\circ} 30^{\prime}$ として，グライド・スロープの下限とする.

このように $20^{\prime}$ 間隔で設定すると, 図 2 のようにBとC の間の $20^{\prime}$ が正規のグライド・スロープゾーンとなり，そ の上方の CとDの間の $20^{\prime}$ が，すこし高くなっているぞと いう警告ゾーンとなり，下方の B $\mathrm{B}$ Aの間の $20^{\prime}$ が，少し 低くなっているぞといら下方の警告ゾーンになる。

PAPI は，このように弧角 $20^{\prime}$ のグライド・スロープの 上下に $20^{\prime}$ ずつの 警告ゾーンを設けて，高くなったり低く なったりするのを防ぎ，正しく $3^{\circ}$ の降下角で進入できる ようになっている.このよらに弧角 $20^{\prime}$ の PAPI を標準 PAPI という.

\subsection{ILS と整合させる場合の進入角設定}

大型ジェット機で安全に効率よく着陸するためには，着 陸進入の段階から, 物理的な量と感覚的な量が完全に一致 していなければならない。

物理的な量とは， $3^{\circ}$ のグライドパスを構成するために必 要な, 滑走路に至る距離, 高度, 速度などのほか, ILSな どの電波の情報であり，感覚量とは PAPI や VASISな どの見え方による判断であって，この二つの量的なものが 完全に整合している必要がある.

ここで大型ジェット機の運航方式を簡単に説明すると, まず, レーダで ILS のコースビームに乗るように誘導さ れてきて, 滑走路の中心線の延長にはいり, 続いて降下角 ビーム（3のグライド・スロープ）をつかんで，着陸進入 にはいるのであるが, ここで PAPI を見ればオングライ ド・スロープの赤, 赤, 白, 白になっていて, それ以後も ILS に沿っていれば, PAPI も必ず赤, 赤, 白, 白である といら関係が成立しなければならない。

逆に PAPI に沿っていれば，必ず ILSにも沿っている ことであって，着陸直前までこの状態を保持するために， PAPI の弧角を標準の $20^{\prime}$ から $30^{\prime}$ に広げ, 必要ならば困
2 の配置図の $\mathrm{D}_{1}$ の距離も調整が行なわれる.

大型ジェット機のグライド・スロープの受信 アンテナ は，パイロットの目より数メートル下方にあるため PAPI の位置 $\left(\mathrm{D}_{1}\right)$ は, ILSのグライド・スロープ発信点よりも 奥になることが多い，ただし PAPI の警告ゾーンの弧角 20'はとのままで広がることはない。
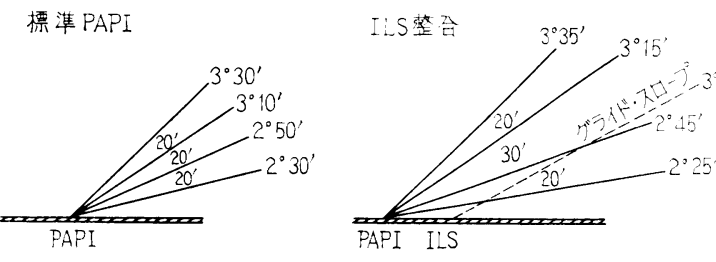

図 5 標準 PAPI とILS 整合の場合の比較

\section{3 特殊な航空機の場合の進入角設定}

櫒準 PAPI のグライド・スロープゾーンの弧角 $20^{\prime}$ は, グライドパスが $2 \sim 4^{\circ}$ までの航空機に対応しているもので あって, ILS と整合させた埸合と, グライドパスが $4 \sim 7^{\circ}$ の間の航空機では $30^{\prime} に な り, さ ら に ~ 7^{\circ}$ 以上の航空機では グライド・スロープゾーンの弧角は $1^{\circ}$ になる.

これは将来の STOL（短い滑走距離で発着できる航空 機）などの運航に対応させたものであって，日本でも航空 宇宙技術研究所で開発されている「飛鳥」は，6～9 ${ }^{\circ}$ の降 下角で着陸進入するため, 降下の感覚量としての基準が必 要なので, 間もなく行なわれる初飛行のため, 6〜9の進 入角の PAPI の設置が予定されている（図 6).

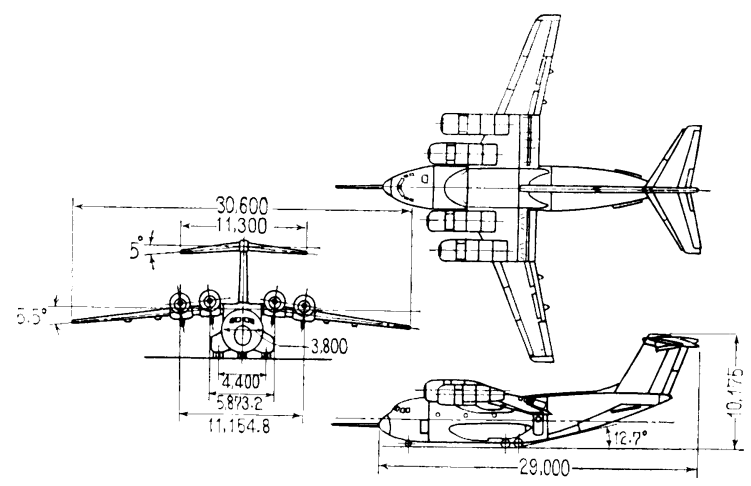

図 6 STOL 飛鳥

\section{4 転 移 層}

図 1 にある転移層が，VASIS に比べて非常に薄いのが PAPI の特長の一つである. 国際民間航空条約では3' 以下 と規定されているが，PAPI の転移層はVASIS の転移層 とは意味が違って，単に白灯と赤灯との境界面であるか ら，理論的にはゼ口で良いわけであるが，技術的な面とコ ストの面から考えると，実用上は3' 以内であれば良いと思 われる。

PAPI の信号が保証されるのは, 滑走路から 4 海里(7.4 $\mathrm{km}, 1$ 海里 $=1,852 \mathrm{~m}$ ）以内ということが，国際民間航空 条約で決められているので, 最も遠い4 マイルの地点で弧 角 $3^{\prime}$ のビームの鉛直幅は $6.6 \mathrm{~m} に な り$, この值は現用ジェ 
ット機の運動特性からすれば，ほとんどゼロに等しいこと になるのである.

沖縄の下地島訓練空港で試験運用された，国産 PAPIの 転移層は $1.5^{\prime}$ 程度であったので, フライトチェックに同乘 して実際の動きの中で見ると，一瞬に変わる切れ味の良さ を示し，転移層の存在を感じなかったほどであった。した

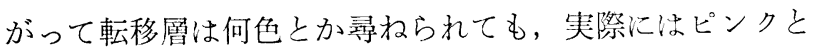
思われるけれども，色を感ずるだけの幅あるい恃間がな いのが実体である.

なぜPAPIには狭い転移層が要求されるかというと, 図 2 の進入角設定図のように，グライド・スロープゾーンの 上下にそれぞれ警告ゾーンがあって，航空機がグライド・ スロープからそれていくのを警告するものであるから，早 く警告ゾーンにはいったことを知るために，切れ味の良さ が必要になる。

一昨年 9 月羽田空港にて試作 PAPI の転移層の夜間実験 が行なわれて, 航空 3 社から参加された約20名のパイロッ 卜は，3,000 mの距離から観测した転移層のシャープなの には一様に驚きの表情を示したものであった。

これが VASIS の場合は, 転移層そのものが警告ゾーン であるから，PAPI と違って15 の幅が必要になるが，こ れは大気が混濁していたり，スモッグがあったり，太陽に 向かって進入した場合に，ピンクの色対比が悪くなって， あるパイロットは白だといい，別のパイロットはピンクだ というように, 感覚量の個人美が出て見掛け上の転移層の 幅にばらつきが出て, 修正操作に手遅れが生じることにも なる・

これが VASISの大きな欠点の一つであって, 逆にパイ ロットが PAPI を好む大きな理由の一つである。

\section{5 PAPI の精度}

\subsection{1 グライド・スロープの精度比較}

PAPI と VASISのグライド・スロープゾーンを滑走路 末端から1マイルごとに，その鉛直幅（高さ）を比較して みると次の 図 7 のようになる.

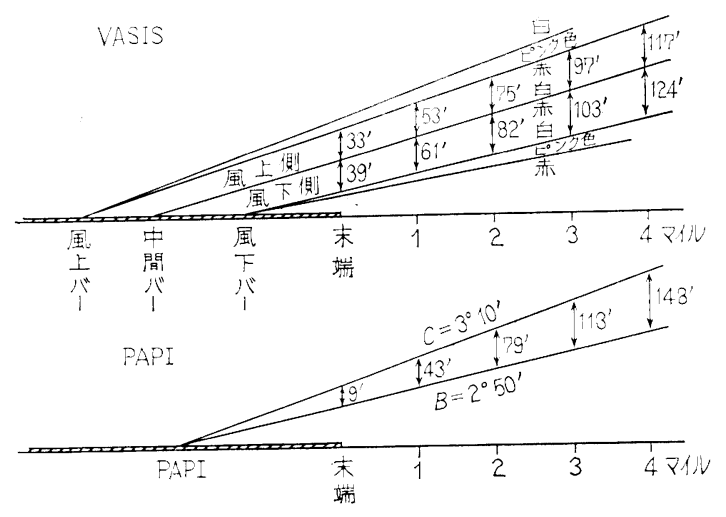

図 7 VASIS と PAPI のグライド・スローブ比較

図のように2 マイル以内はPAPI の汪らが精度が高くな り，2マイル以遠では逆に VASIS の注うが精度が良い。 これはPAPIが 1 本のバーから末広がりにビームが出てい るためで, PAPI の大きな特長の一つで, 滑走路に近づく
ほど精度が上がり，ILSに近い精度になって，悪天候で も使用できる視覚援助施設となるのであって，このため Precision (精密) とい5名がついている.これが今後の 航空機の運航には必要な条件であって, VASISでは遠く 及ばないところでもめる。

滑走路の近くでグライド・スロープの精度を, 英国王立 航空機研究所 (RAE) で調查比較したのが図 8 である が，PAPI の精密さがよくわかる.
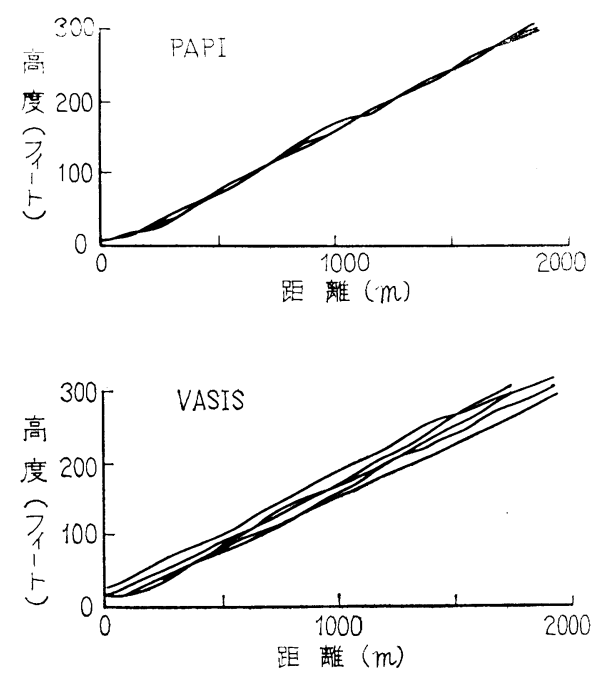

図 8 PAPI と VASIS の精度比較 着陸進入航跡のばらつきを比較したものである.

この理由はグライド・スロープ自身が薄いことと，転移 層がきわめて薄いため，進入中に高くなったり，低くなっ たりしたとき，警告ゾーンにはいったことがすぐわかり， 早い時期に修正できるためである.

\subsection{2 接地点のばらつきの比較}

悪天候下の着陸では，横風が強かったり，雨や雪で滑走 路が滑るときには，接地点のばらつき範四が狭いことがた いせつである。

着陸進入では， 3 のグライドパスで降下することが原則 であるから，常汇眼高の 20 倍前方がエイミングポイントに なることは前述のと趽りで, 滑走路末端通過時の高度の 20 倍前方に接地することになる(例, 高度 50 フィートで末端

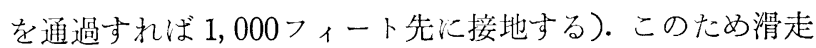
路末端上空に沶ける，グライド・スロープゾーンの鉛直幅 の少ないほど，接地点のばらつき範囲が少ないことにな る.

図 7 によれば, PAPI のグライド・スロープゾーンの末 端上の鈶直幅は 9 フィートであるから，接地点はその20倍

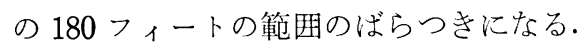

これに対してVASIS のばらつきは図 7 で風上侧で 660 フィート，風下側で $780^{\prime}$ の範囲になり，PAPIばらつき範 因がいかに少ないか，いいかえれば，いかに精密であるか がわかる。

\section{6 PAPI の見え方と有効視認距離}

\section{6.1 PAPI の見え方}

オングライド・スロープで進入中の PAPI は, 図 3 や図 
2 に示すように赤, 赤, 白, 白に見える. これは $2^{\circ} 50^{\prime}$ か ら $3^{\circ} 10^{\prime}$ の間で降下していることで，これを通常 $3^{\circ}$ のグ ライドパスといっているのである.

何らかの理由で $2^{\circ} 50^{\prime} よ り$ 低くなったときは，PAPIの 見え方が瞬間に赤，赤，赤，白になる。これは少し低くな っているぞ, といら警告であるから, 静かに赤, 赤, 白, 白に帰るように操作すればよい。このようにグライド・ス ロープからずれたことの発見が早いのも PAPI の特長で, 下地島でのパイロットのコメントでも，この点がVASIS に此べて非常によくて，右侧にあるVASISがじゃまにな るといらのがあった。

また PAPI の警告ゾーンの幅は, VASISの15'に比べて $20^{\prime}$ とってあるので，あわてることなくスムーズな操作で 修正すればよい.しかし 4 個全部赤になったときは，進入 角が $2^{\circ} 30^{\prime}$ 以下になっているので，最低進入角の下側に設 定されている無障害表面（これ以下に降下してはならない 面）に近くなるので早く引き上げなければならない。

\subsection{2 有効視認距離}

PAPI の視念距離は, VASIS と同じ 4 海里 $(7.4 \mathrm{~km})$ が保証されなければならないことになっている。人間の目 の生理機能から，単に見えるといらだけならば，夜間清澄 な大気の中で，奈良の上空から大阪空港の VASIS の白灯 が橙色に变色して見えるけれども，これでは進入角指示の 情報にはならず，単に大阪空港であるとの位置情報だけで ある・

人間の目には白灯は遠くなれば橙色に見兄, 進入角指示 の光ビームも末広がりになって, 正確な機能を果たさなく なり，赤，白の色灯を使用するPAPIでも，スモッグなど があると赤，白の色対比が覀くなるので，どんな条件が覀 くても4マイルは見えなければならないのである.

さらに運航面から考光ても，滑走路の手前で大事故が発
生することがあるが，これを防ぐためには滑走路末端まで ILS 情報と PAPI の視覚情報を完全に一致させておかな 防ばならい。 ILS で降下して雲下に出た瞬間に一瞥 して，グライド・スロープからのずれが判定できるために は，ピンクゾーンのない PAPIが必要になる。このため 4 マイル以内に正確な視覚情報が強く要求されるようにな り，それより距離が遠くなるほど灯火の情報は不確実にな るので，無線情報に重点が移っていくけれども，㐁の中を 無線情報で降下して, 雲下に出た瞬間にPAPIの灯火情報 が目にはいると，誰しも「浪っと」するものである。これ が灯火情報の暖かさである。

\section{4. おわりに}

以上PAPIについて簡単に紹介しましたが，今回下地島 空港汇設置運用された PAPI は, 照明学会およびメーカー の諸先生のご努力の結晶によって，すばらしい性能のもの ができて，上空から見た筆者も思わず快哉を叫んだ次第で す. パイロットのコメントにも，滑走路の片側で点灯して いたVASISがじゃまになったというのがあったほどに， パイロットの要求していたものが，今ここに出現したわけ で，紙面を借りて開発に従事された諸先生に深く感謝いた します。

\section{参 考 文 献}

(1) RAE Technical Report No. 76123

(2) PAPI 運輸省航空局管制保安部照明課

（3） 国際民間航空条約 第14付属書

(4) AERODROME DESIGN MANUAL PART 4

(5) ICAO VAP 第 9 回会議報告書

(6) PAPI に関する調查研究報告書 昭和58年 3 月 照明学会

(7) 航空灯火システム 日本航空

（受付1985年 1 月 21日） 